\title{
Analisis Kesalahan Siswa Kelas VIII SMP Negeri 1 Sindangkerta dalam Mengerjakan Soal Segitiga dan Segiempat
}

\author{
Halimatus'sya'diyyah ${ }^{1}$, Risma Amelia ${ }^{2}$ \\ ${ }^{1,2}$ Prodi Pendidikan Matematika, Fakultas pendidikan matematika dan SAINS, IKIP Siliwangi, \\ Jl. Terusan Jend. Sudirman, Baros, Kec. Cimahi Tengah, Kota Cimahi, Jawa Barat \\ halimatussyadiyyah14@gmail.com
}

\begin{abstract}
This study aims to identify and describe student errors and the causal factors in solving triangle and quadrilateral problems. This research was conducted on 30 junior high school students in the Sindangkerta area. The research was carried out in the even semester of the 2020/2021 Academic Year. Data collection techniques using 5 items of description and documentation of the results of student answers and followed by data analysis using descriptive and drawing conclusions. The results obtained that student make mistakes include 1) errors in determining the formulas of triangles and quadrilaterals, 2) errors using formulas or theorems 3) students' errors in completing the problem steps. The factors that cause it are 1) Students tend not to understand the content of the questions 2) Students do not know which formula should be used 3) Students tend to memorize rather than understand the material and formulas, 4) Lack of practice about triangles and quadrilaterals.
\end{abstract}

Keywords: error, quadrilateral, triangle, descriptive

\begin{abstract}
Abstrak
Penelitian ini bertujuan untuk mengetahui dan mendeskripsikan kesalahan siswa serta faktor penyebab dalam menyelesaikan soal segitiga dan segiempat. Penelitian ini dilakukan pada siswa SMP di daerah Sindangkerta yang berjumlah 30 orang. Penelitian dilaksanakan pada semester genap Tahun Pelajaran 2020/2021. Teknik pengumpulan data mengunakan 5 butir soal uraian dan dokumentasi hasil jawaban siswa, dan dilanjutkan dengan analisis data menggunakan deskriptif serta penarikan kesimpulan. Hasil penelitian yang diperoleh bahwa siswa membuat kesalahan meliputi 1) Kesalahan dalam menentukan rumus-rumus segitiga dan segiempat, 2) kesalahan menggunakan rumus atau teorema 3) kesalahan siswa dalam mengerjakan penyelesaian langkah-langkah soal. Faktor yang menjadi penyebabnya adalah 1) Siswa cenderung tidak memahami isi soal 2) siswa tidak mengetahui rumus mana yang seharusnya digunakan 3 ) siswa cenderung menghafal daripada memahami materi dan rumus, 4) Kurangnya latihan soal segitiga dan segiempat.
\end{abstract}

Kata kunci: kesalahan, segiempat, segitiga, deskriptif

Copyright (c) 2021 Halimatus'sya'diyyah, Risma Amelia

$\triangle$ Corresponding author: Halimatus'sya'diyyah

Email Address: halimatussyadiyyah14@gmail.com (Jl. Terusan Jend. Sudirman, Kota Cimahi, Jawa Barat)

Received 25 July 2021, Accepted 16 August 2021, Published 24 August 2021

\section{PENDAHULUAN}

Kemajuan suatu bangsa dipengaruhi oleh adanya keberadaan pendidikan. Untuk memperoleh pendidikan yang maju, tinggi, dan berkembang diperlukan adanya suatu perencanaan yang berhubungan dengan tujuan nasional pendidikan bagi suatu bangsa. Indonesia dalam Sistem Pendidikan Nasional Nomor 20 Tahun 2003 menyatakan bahwa tujuan pendidikan nasional adalah untuk mencetak generasi bangsa yang beriman dan bertakwa, berbudi luhur, cerdas, dan kreatif. Dalam mencapai tujuan pendidikan nasional itu diperlukan kurikulum yang menunjang untuk diberikan kepada peserta didik dalam tingkat satuan pendidikan masing-masing seperti salah satunya satuan pendidikan sekolah dasar, Salah satu mata pelajaran yang mempengaruhi kemajuan pendidikan dari tingkat dasar sampai tingkat menengah adalah matematika. 
Matematika merupakan salah satu ilmu dasar yang mendukung kemajuan perkembangan ilmu pengetahuan dan teknologi. Selain dapat berkembang secara mandiri matematika juga berkembang atas tuntutan kebutuhan bidang lainnya.(Hanifah, 2019) mengatakan bahwa matematika sangat penting untuk dipelajari, matematika merupakan salah satu mata pelajaran yang diajarkan di sekolah dari tingkat dasar hingga menengah yang memiliki tempat tersendiri dan menjadi fokus utama yang sangat penting di setiap tingkatan sekolah, karena pengaruh besar dalam pendidikan serta kemajuan teknologi salah satunya adalah matematika. Dalam bidang pendidikan formal di lingkungan sekolah khususnya, matematika dijadikan acuan standar dalam syarat kelulusan. Namun pada kenyataannya matematika justru dianggap sebagai mata pelajaran yang sulit dipahami dan hanya orang tertentu yang dapat mempelajarinya. Anggapan ini membuat siswa takut untuk mempelajari matematika sehingga siswa menjadi pasif di dalam pembelajaran (Trianto, 2007)

Menurut Wibowo (Shulhani, 2013) bahwa peran terbesar dalam suatu pembelajaran dan pembentukan karakter siswa adalah seorang guru. Terdapat suatu sudut pandang bahwa semakin tinggi level suatu pendidikan formal maka semakin rendah peran serta kontribusi guru dalam kesuksesan pembentukan karakter. Menurut (Zakiah, Fatimah, \& Sunaryo, 2020) bahwa cara untuk mengembangkan kemampuan inovatif, responsif, kreatif, terampil, berdaya saing, dan kooperatif adalah salah satu fungsi dari pendidikan. Sehingga dalam konteks ini, guru harus menemukan cara yang terbaik dalam menyampaikan materi yang akan diajarkan sehingga siswa mampu mengingat lebih lama konsep materi tersebut. Sejalan dengan pendapat Sumarmo (Purwasih, 2015) menyatakan agar pembelajaran dapat memaksimalkan proses serta hasil belajar maematika, perlu adanya dorongan dari guru agar siswa terlibat diskusi secara aktif, bertanya dan menjawab sebuah pertanyaan, berpikir kritis, memahami agar dapat menjelaskan jawaban yang diberikan, dan memberikan alasan untuk jawaban yang diajukan.

Salah satu materi yang dipelajari siswa kelas VIII di tingkat sekolah menengah pertama adalah materi Segitiga dan Segiempat. Materi tersebut dipelajari di awal semester genap pada sekolah yang menggunakan kurikulum 2013, termasuk SMPN 1 Sindangkerta. Materi Segitiga dan Segiempat dapat dikatakan sebagai materi yang tidak terlalu sulit. Bentuk Segitiga dan Segiempat merupakan bagian dari geometri dua dimensi, akan tetapi masih sangat banyak siswa yang merasa kesulitan dalam mengerjakan soal dengan materi segitiga dan segiempat tersebut,

Menurut Majid, (Majid \& Abadi, 2019), kemampuan pemahaman konsep matematis siswa pada materi segitiga dan segiempat ternyata masih dikategorikan dalam tingkatan yang rendah, Karena melihat jawaban siswa yang terdapat pada hasil dan pembahasan dimana terlihatjelas bahwa siswa masih belum mampu dalam hal kemampuan pemahaman konsep matematika, lalu menyusun bukti akan alasan terhadap solusi yang relevan, dan dapat memaparkan pernyataan matematika secara tertulis, serta dapat menarik kesimpulan pernyataan dalam bentuk lisan, tertulis, gambar, dan diagram.

Pemahaman konsep matematika merupakan bagian yang sangat penting dalam pembelajaran matematika. Pemahaman konsep merupakan salah satu kecakapan atau kemahiran matematika yang diharapkan dapat tercapai dalam belajar matematika yaitu dengan menunjukkan pemahaman 
konsep matematika yang dipelajarinya, menjelaskan keterkaitan antar konsep dan mengaplikasikan konsep atau algoritma secara luwes, akurat, efisien, dan tepat dalam pemecahan masalah (Hadjar, 2014) Pentingnya pemahaman konsep pada bangun datar segitiga dan segiempat pada siswa SMP memang sangatlah penting, namun kenyataan belum sepenuhnya optimal. Kondisi di lapangan menggambarkan kontradiktif dari yang diinginkan. Siswa hanya menghafal rumus bangun datar yang sudah ada dan kurang mampu menguasai sifat-sifat dari bangun datar tersebut dengan konsep yang dimiliki. Telah diketahui bahwa semua materi matematika yang ada di sekolah mengandung aspek pemahaman konsep, karena kemampuan mendasar dalam belajar matematika adalah memahami konsep terlebih dahulu (Hakim, 2019)

Kesalahan dalam memecahkan masalah matematika sering terjadi, baik secara lisan maupun tulisan. Selama proses belajar mengajar matematika, siswa akan menghadapi banya kendala karena pemecahan masalah dalam matematika adalah keterampilan yang sangat kompleks. Terkadang siswa tahu cara menjawab pertanyaan yang diajukan, namun ceroboh dalam perhitungan. Menurut Laporan Studi Matematika dan Ilmu Pengetahuan Internasional ketiga berdasarkan hasil TIMSS (Nurdiana \& Asmah, 2014) pada tahun 1999 siswa Indonesia berda diperingkat ke 32, pada tahun 2003 berada pada peringkat ke 37 dan pada tahun 2007 berada di peringkat ke 35. Mengatakan bahwa siswa indonesia berada diperingkat ke 34 dari 38 negara di tingkat Internasional ini menunjukkan penguasaan matematika antar siswa di Indonesia secara kesluruhan masih lemah.

Kesalahan siswa dalam mengerjakan soal matematika juga cenderung kepada soal cerita, dikarenakan siswa mengalami beberapa kesulitan(Adilla, Zanthy, \& Yuspriyati, 2020). Kesulitankesulitan tersebut yaitu 1) Kesalahan dalam menentukan rumus-rumus segitiga dan segiempat, 2) kesalahan menggunakan rumus atau teorema 3) kesalahan siswa dalam mengerjakan penyelesaian langkah-langkah soal. Faktor yang menjadi penyebabnya adalah 1) Siswa cenderung tidak memahami isi soal 2) siswa tidak mengetahui rumus mana yang seharusnya digunakan 3) siswa cenderung menghafal daripada memahami materi dan rumus, 4) Kurangnya latihan soal segitiga dan segiempat.

Perlu adanya saran-saran yang harus disampaikan kepada siswa untuk menghindari banyaknya kesalahan dalam menyelesaikan soal cerita matematika berdasarkan pada prosedur Newman, yaitu: (1) guru perlu menyarankan siswa agar lebih berhati-hati dalam membaca soal; (2) guru memastikan pemahaman siswa terhadap materi dan penggunaan rumus matematika;(3) guru memberikan penguatan kembali kepada siswa terhadap materi matematika; (4) guru meminta siswa untuk memeriksa kembali hasil jawabannya; dan (5) guru membiasakan memberikan contoh dalam bentuk soal cerita (Magfirah, Maidiyah, \& Suryawati, 2019)

Berdasarkan uraian di atas perlu adanya evaluasi pembelajaran kepada siswa untuk mengurangi kebiasaan menghafal dan mengingat menjadi kebiasaan pembelajaran yang kritis serta kreatif. Dengan diadakan penelitian ini diharapkan para guru atau para pembaca dapat mengantisipasi kesalahankesalahan yang dilakukan siswa agar tercapainya tujuan pembelajaran materi segitiga dan segi empat 


\section{METODE}

Jenis penelitian yang digunakan dalam penelitian ini adalah deskriptif kualitatif. Tujuan penelitian ini adalah untuk menganalisis bagian -bagian kesalahan siswa dalam mengerjakan soal materi segitiga dan segiempat. Waktu penelitian dilaksanakan pada semester genap Tahun Pelajaran 2020/2021. Subjek dalam penelitian ini yaitu siswa kelas VIII satu tingkat diatas siswa yang sedang mempelajari materi segitiga dan segiempat yang bertujuan untuk mengetahui kesalahan-kesalahan siswa dalam mengerjakan soal materi segitiga dan segiempat yang telah mereka pelajari pada tahun ajaran sebelumnya. Yaitu bertempat di salah satu sekolah menengah pertama di Wilayah Bandung Barat, dimana hanya diambil satu kelas saja sebagai sampel dengan jumlah siswa sebanyak 30 orang. Teknik pengambilan data yaitu tes sebanyak 5 butir soal uraian dan untuk menganalisis data kesalahan siswa dalam menyelesaikan soal segitiga dan segiempat diambil dari dokumentasi digunakan sebagai pengarsipan data-data penelitian, upaya ini dilakukan agar peneliti dapat memperoleh hasil kerja siswa dan menganalisis kesalahan apa saja yang dialami oleh siswa serta dapat menjadi bahan acuan dan perbaikan untuk setiap guru dalam proses pembelajaran pada materi segitiga dan segiempat yang dianggap sulit agar mencapai tujuan pembelajaran yang maksimal. Sehingga kedepannya siswa dapat mengikuti proses pembelajaran dengan pemahaman yang baik dengan mudah jika guru menggunakan pendekatan pembelajaran yang efisien untuk setiap pembelajaran matematika khususnya pada materi segitiga dan segiempat.

\section{HASIL DAN DISKUSI}

Dalam penelitian ini, metode yang digunakan adalah deskriptif kualitatif yang bertujuan untuk mendeskripsikan kesalahan siswa dalam menyelesaikan soal Segitiga dan Segiempat. Menurut (Zulfah, 2017)deskriptif kualitatif yaitu menggambarkan kesalahan-kesalahan yang dilakukan siswa dengan menggunakan kata-kata. Instrumen yang digunakan pada penelitian ini yaitu lembar tes soal Segitiga dan Segiempat yang memuat 5 butir soal dalam bentuk uraian. Subjek penelitian ini adalah 30 orang siswa kelas VIII SMP NEGERI 1 Sindangkerta tahun akademik 2020/2021. Setelah siswa selesai mengerjakan tes yang diberikan, selanjutnya hasil jawaban tertulis siswa dianalisis untuk mengetahui jenis kesalahan-kesalahan yang dilakukan oleh siswa. Menurut hasil penelitian (Muzaky, 2017) adapun indikator dari masing- masing jenis kesalahan yang telah disesuaikan dengan konteks penelitian dapat dilihat pada tabel 2 berikut ini.

Tabel 1. Jenis-Jenis Kesalahan beserta Indikatornya

\begin{tabular}{|l|l|}
\hline \multicolumn{1}{|c|}{ Jenis Kesalahan } & \multicolumn{1}{c|}{ Indikator Kesalahan } \\
\hline Kesalahan Konsep & $\begin{array}{l}\text { Menetukan rumus atau teorema atau definiisi untuk menjawab suatu } \\
\text { masalah matematka }\end{array}$ \\
\hline & $\begin{array}{l}\text { Menuliskan rumus atau teorema atau definisi untuk menjawab suatu } \\
\text { masalah matematika }\end{array}$ \\
\hline Kesalahan Prinsip & Keteraturan langkah-langkah dalam menyelesaikan masalah matematika \\
\hline Kesalahan operasi & Menggunakan aturan operasi atau perhitungan \\
\hline
\end{tabular}


Analisis Kesalahan Siswa Kelas VIII SMP Negeri 1 Sindangkerta Dalam Mengerjakan Soal Segitiga dan Segiempat,

Dari hasil tes yang diberikan kepada 30 orang siswa, terdapat beberapa siswa yang melakukan kesalahan dalam mengerjakan setiap soal Segitiga dan Segiempat yang diberikan. Adapun berikut indikator soal yang diberikas kepada siswa:

Tabel 2. Indikator Soal Tes Siswa

\begin{tabular}{|l|c|}
\hline \multicolumn{1}{|c|}{ Indikator Pencapaian Kompetensi } & No soal \\
\hline Menentukan besar sudut pada bangun datar segitiga & 1 \\
\hline Menghitung luas trapesium & 2 \\
\hline Menyelesaikan masalah yang berkaitan dengan penerapan segitiga dan segiempat & 3 \\
\hline Menganalisis luas bangun trapesium & 4 \\
\hline Mengkalkulasikan penerapan luas jajargenjang & 5 \\
\hline
\end{tabular}

Berikut ini adalah diagram kesalahan pengerjaan siswa dan hal-hal yang menyebabkan kesalahan tersebut yaitu:

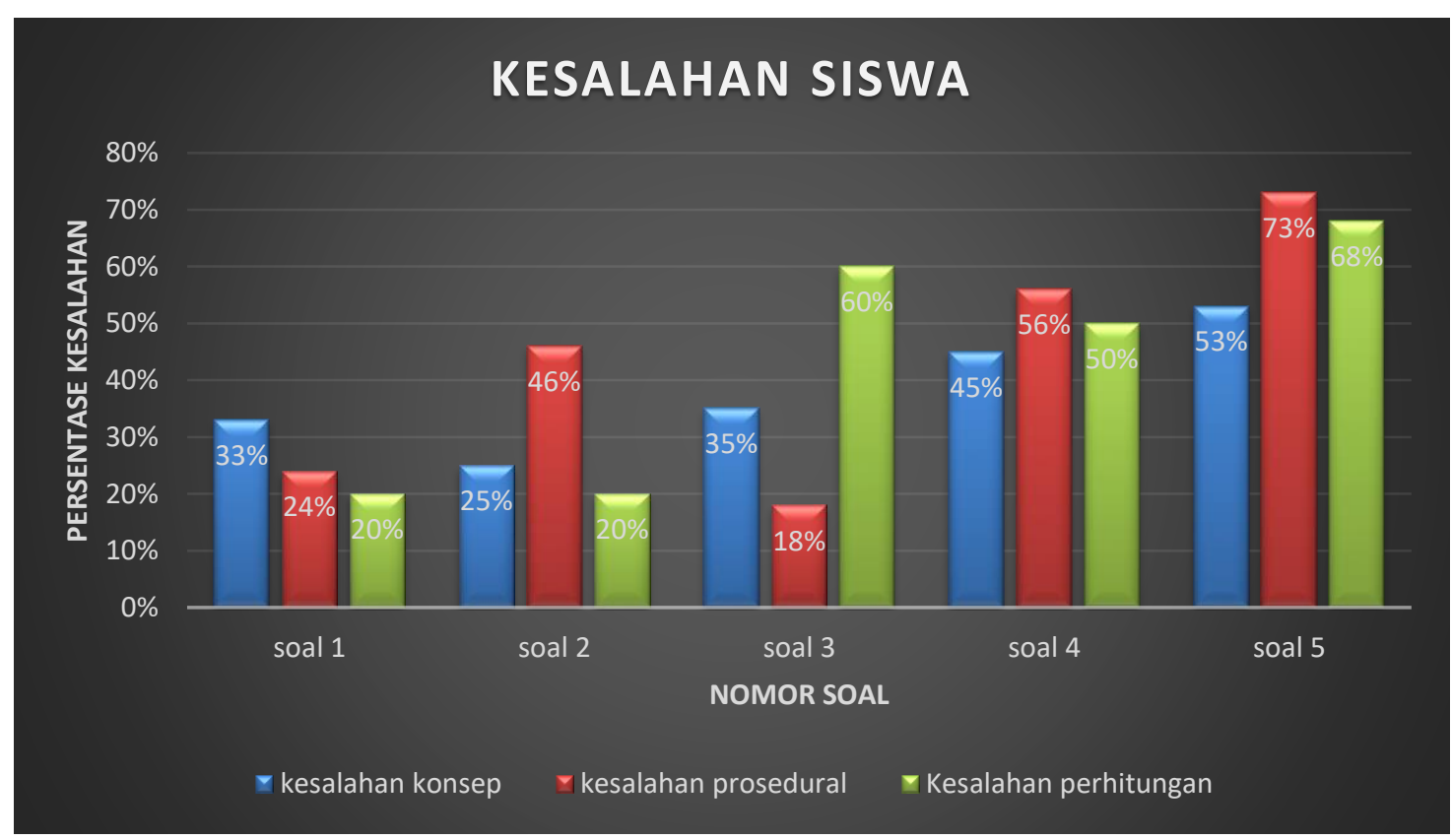

Diagram 1. Persentase Hasil Tes pada Setiap Indikator

Dari diagram 1. diatas dapat terlihat bahwa kesalahan siswa dalam menyelesaikan soal materi segitiga dan segiempat terdapat 3 macam kesalahan yaitu kesalahan konsep, kesalahan prosedural, dan kesalahan perhitungan. Dari diagram diatas juga dapat terlihat pada persentase kesalahan jawaban siswa bahwa rata-rata dari setiap kesalhan di atas paling banyak kesalahan prosedural, penyebab terjadinya kesalahan prosedural terdapat pada kesalahan keteraturan dalam menyelesaikan langkah- langkah untuk menjawab suatu masalah matematika yang dianjurkan untuk siswa dalam mencantumkan diketahui dan ditanyakan agar siswa mengetahui langkah awal yang harus dilakukan untuk memecahkan soal tersbut. Berdasarkan hasil analisis dari jawaban siswa tersebut kesalahan selalu terjadi pada setiap jawaban pengerjaan siswa, yang disebabkan kurangnya ketelitian dan kurangnya keterampilan siswa dalam 
mencari solusi untuk memecahkan suatu persoalan dalam soal tersebut. Kesalahan konsep yg dilakukan siswa pada soal nomor 1 ada $33 \%$,soal nomor 2 sebanyak 25\% dan soal nomor 3 sebanyak $35 \%$, soal nomor 4 sebesar $45 \%$ dan 5 menunjukan lebih dari $50 \%$ yang dapat menunjukkan bahwa kesalahan siswa dalam menjawab soal paling banyak ada pada setiap indikator kesalahan ada pada nomor 3,4 dan 5 dengan jumlah keseluruhan siswa sebanyak 30 orang menunjukkan hanya kurang dari 15 org yg bisa menyelesaikan soal tersebut dengan benar, dari hasil analisis berikut ini diharapkan menjadi acuan dan gambaran kesalahan siswa agar tercapainya tujuan pembelajaran yang maksimal.

Kesalahan siswa dalam mengerjakan soal matematika cenderung kepada soal cerita, dikarenakan siswa mengalami beberapa kesulitan (Adilla et al., 2020) Kesulitan-kesulitan tersebut yaitu: (1) siswa kurang memahami konsep; (2) siswa kurang tepat dalam mentransformasikan soal; (3) siswa kurang tepat dalam melakukan perhitungan; dan (4) kesalahan mengerjakan soal berbentuk cerita

Data dibawah ini merupakan pembahasan mengenai analisis kesalahan jawaban siswa dalam menyelesaikan soal materi segitiga dan segiempat

\section{Analisis Soal Nomor 1}

Paman akan membuat sebuah taman dengan berbagai bentuk segitiga namun ia belum menentukan ukurannya jika besar salah satu segitiga adalah $20^{\circ} \mathrm{x}$ maka dapatkah kamu memprediksi besar sudut lainnya?

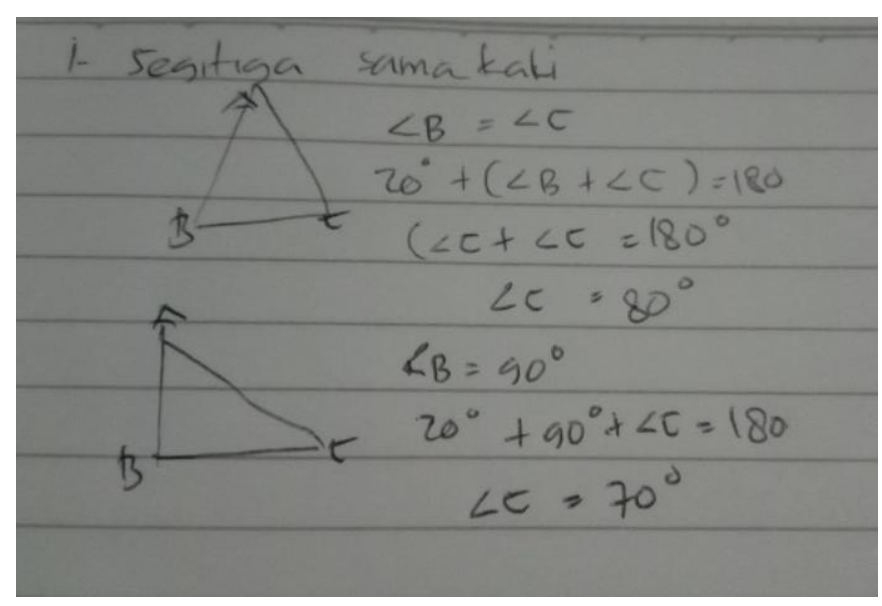

Gambar 1. Kesalahan Jawaban siswa soal nomor 1

Berdasarkan hasil jawaban siswa Gambar 1 masih kurang tecapai dengan baik. Siswa tidak mampu menyelesaikan soal secara terurut dari informasi yang diketahui dari soal. Penyebabnya adalah siswa hanya mengingat bagaimana membentuk sebuah bangun datar segitiga tersebut dan tidak memperhatikan soal dengan baik. Dari gambar 1 diatas, kesulitan yang dialami siswa sehingga siswa membuat kesalahan saat menjawab soal adalah siswa kurang menguasai konsep atau prasyarat mengenai materi segitiga dan segi empat. 
Analisis Kesalahan Siswa Kelas VIII SMP Negeri 1 Sindangkerta Dalam Mengerjakan Soal Segitiga dan Segiempat, Halimatus 'sya'diyyah, Risma Amelia

\section{Analisis Soal Nomor 2}

Diketahui sebuah trapesium ABCD Memiliki panjang BC $25 \mathrm{~cm}$ dan panjang AD $17 \mathrm{~cm}$ dengan tinggi AE maka jika luas Persgi ABFE adalah $270 \mathrm{~cm}^{2}$ dapatkah kamu menghitung kemungkina luas trapesium ABCD

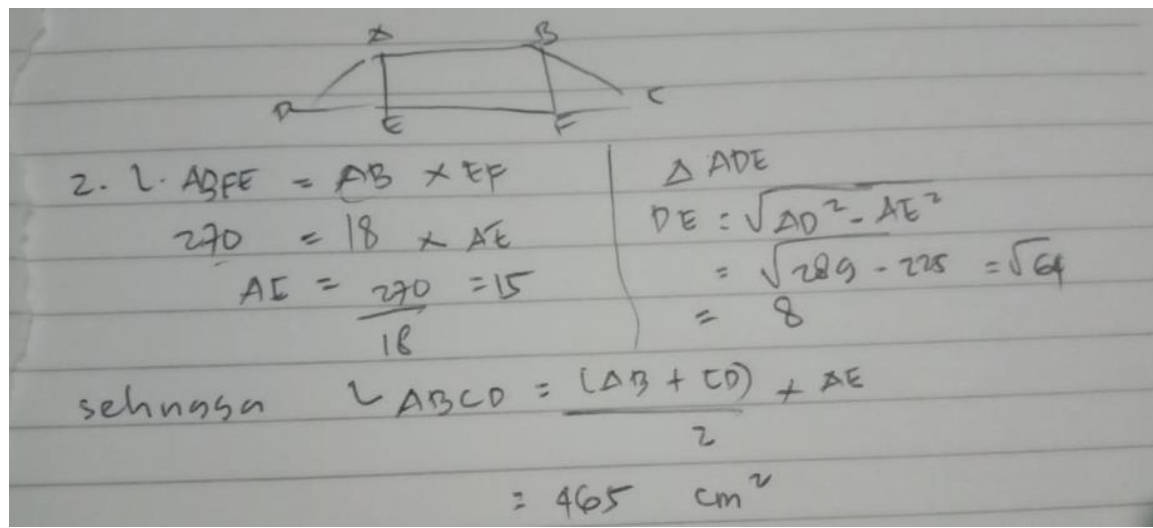

Gambar 2. Kesalahan Jawaban siswa pada soal nomor 2

Berdasarkan hasil jawaban siswa Gambar 2 masih kurang tepat, karena siswa tidak memperhatikan apa yang diketahui dan yang ditanyakan. Siswa masih kebingungan bagaimana cara penyelesaiannya, serta siswa tidak menyimpulkan dan menuliskan satuan panjang dari masing-masing sisi trapesium tersebut. Faktor penyebab kesalahan siswa pada indikator soal ini adalah kurang terbiasanya siswa dalam mengerjakan soal-soal materi segitiga sehingga mudah lupa dalam penulisan satuan panjang setiap sisi segitiga

\section{Analisis Soal Nomor 3}

Bila suatu kebun berturut-turut bebentuk persegi dengan ukuran 18 x 12 dan berencana memagari kebun tersebut setiap $2 \mathrm{~m}$ dan setiap $1 \mathrm{~m}$ akan ditancapi tiang berapa banyak tiang yang dibutuhkan?

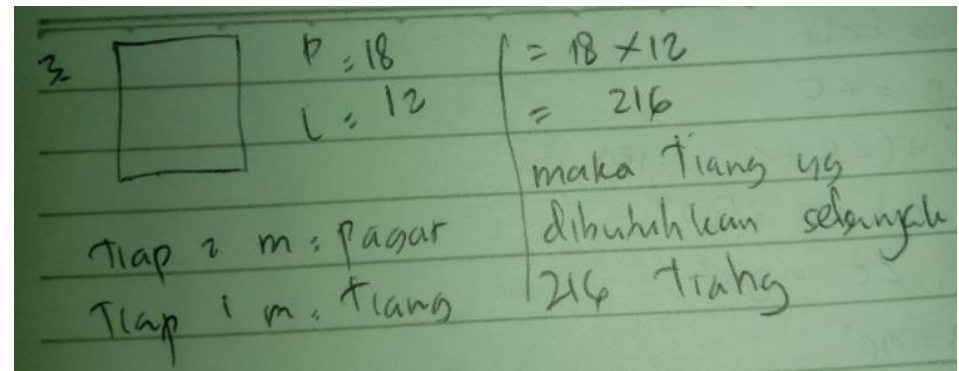

Gambar 3. Jawaban siswa pada soal nomor 3

Berdasarkan hasil jawaban siswa Gambar 3 masih kurang tepat. Kesalahan pada jawaban ini siswa tidak mengetahui atau tidak mengingat rumus dari sebuah bangun datar segiempat trapesium siswa juga kurang memahami operasi perhitungan sehingga operasi perhitungan yang dilakukan oleh siswa tidak tepat.

\section{Analisis Soal Nomor 4}

Bangun $\mathrm{ABCD}$ merupakan persegi dengan panjang sisi $24 \mathrm{~cm}$ AG=EF=EG=FH=1/3 AD, Dapatkah kamu menganalisis luas bangun yang diarsir berikut ini? 


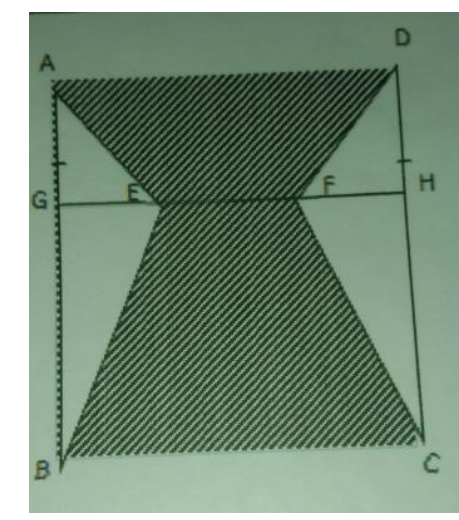

Gambar 4. Soal nomor 4

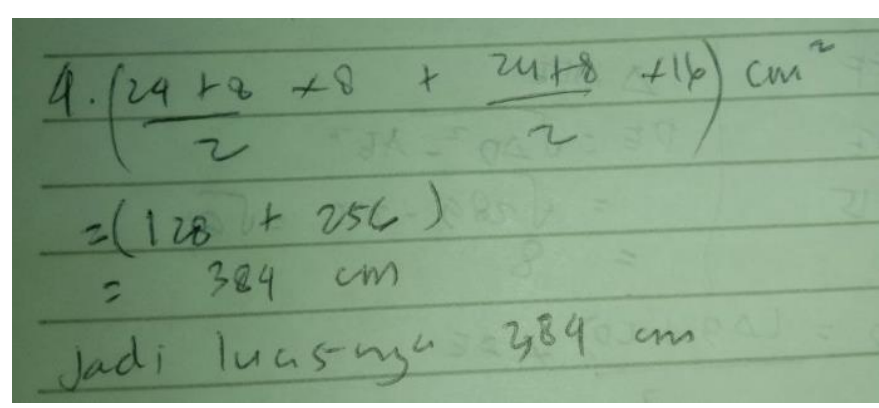

Gambar 5. Kesalahan Jawaban siswa pada soal nomor 4

Berdasarkan hasil jawaban siswa Gambar 8 belum terpenuhi dengan maksimal. Siswa tidak menuliskan apa yang diketahui dan apa yang ditanyakan pada soal tersebut. Siswa juga tidak mencantumkan proses pengerjaan soal darimana hasil tersebut bisa didapat.

\section{Analisis Soal Nomor 5}

Ayah memiliki sepetak sawah berbentuk jajargenjang ABCD dengan ukuran alas adalah $15 \mathrm{~m} \mathrm{O}$ adalah titk potong dari jajar genjang tersebut, dalam jajargenjang tersebuit terdapat segitiga AOB dan tinggi jajargejang adalah 1:2 dengan segitiga AOB jika ayah ingin menjual sawahnya seharga Rp. $200.000 / \mathrm{m}^{2}$ maka berapa uangg yang harus dikeluarkan oleh pembeli?

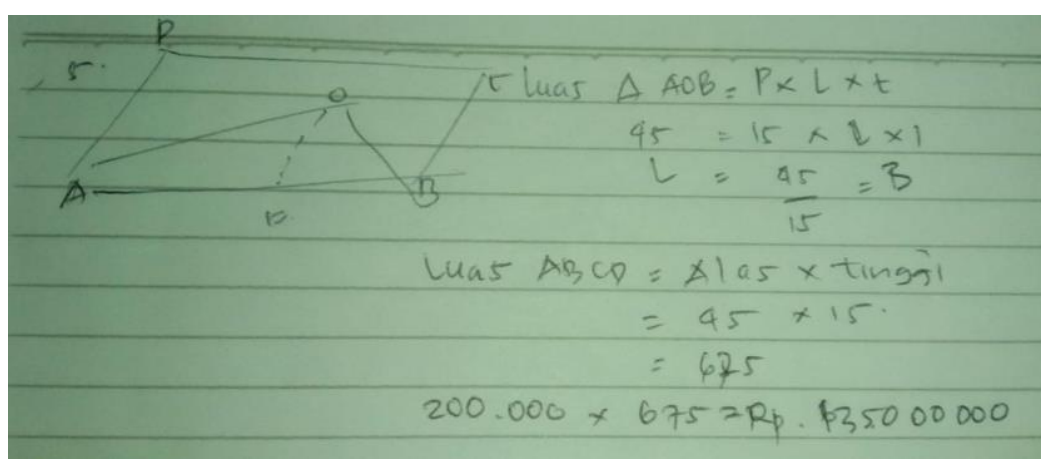

Gambar 6. Kesalahan Jawaban siswa pada soal nomor 5 
Berdasarkan hasil jawaban siswa Gambar 10 terdapat banyak kesalahan pada jawaban, yaitu siswa tidak tepat dalam operasi perhitungan dan tidak tepat dalam penggunaan rumus bangun datar jajar genjang sehingga mengakibatkan jawaban yang didapatnya kurang tepat. Dalam hal ini terlihat jelas siswa masih merasa bingung dengan rumus-rumus yang ada pada materi segitiga dan segiempat sehingga antara rumus satu dengan rumus yang lainnya selalu tertukar.

Berdasarkan penjelasan hasil penelitian di atas secara umum kesalahan yang banyak dilakukan oleh siswa adalah dalam penulisan satuan dan juga penerapan rumus bangun datar segiempat. Hal ini disebabkan oleh kurangnya siswa dalam mengingat dan memahami materi segitiga dan segiempat serta ada kesalahan dalam memahami soal, sehingga mengakibatkan siswa melakukan kesalahan-kesalahan pada tahap selanjutnya. Selain itu, siswa tidak teliti dalam melakukan operasi perhitungan oleh karena itu masih banyak siswa melakukan kesalahan pada setiap proses pengerjaan soal tes.

\section{KESIMPULAN}

Berdasarkan hasil dari penelitian yang telah penulis peroleh dan permasalahan yang telah penulis rumuskan, terdapat kesimpulan sebagai berikut 1) Siswa keliru dalam menentukan titik yang terdapat pada soal tes. Penyebabnya adalah siswa hanya menghafal bagaimana bentuk persegi panjang bisa terbentuk dan tidak memperhatikan soal dimana seharusnya titik ditentukan. 2) Siswa tidak menuliskan satuan panjang dari masing-masing sisi segitiga. Faktor penyebab kesalahan siswa pada indikator soal ini adalah kurang terbiasanya siswa dalam mengerjakan soal-soal sehingga mudah lupa dalam penulisan satuan panjang. 3) Siswa tidak memahami operasi hitung sehingga membuat jawabannya salah. Faktor penyebab karena siswa kurang latihan soal perhitungan matematika. 4) Siswa tidak menuliskan apa yang diketahui dan apa yang ditanyakan pada jawabannya, sedangkan hal tersebut penting dalam proses pengerjaan soal matematika. Akibatnya banyak kesalahan yang dilakukan oleh siswa dalam menjawab soal pada indikator kesalahan prosedural yang berhubungan erat dengan keteraturan langkah-langkah penyelesaian, dengan menuliskan apa yang diketahui dan ditanyakan pada soal tersebut diharapkan siswa dapat menentukan langkah pertama untuk menyelesaikan soal matematika. 5) Terdapat banyak kesalahan pada jawaban, hal ini dikarenakan siswa tidak tepat dalam operasi perhitungan dan tidak tepat dalam penggunaan rumus sehingga mengakibatkan jawaban yang diperolehnya kurang tepat. Dalam hal ini terlihat jelas siswa masih merasa bingung dengan rumus-rumus yang ada pada materi segitiga dan segiempat sehingga antara rumus satu dengan rumus yang lainnya tertukar.

\section{UCAPAN TERIMAKASIH}

Ucapan terimakasih peneliti sampaikan kepada pihak-pihak yang telah membantu dalam penyususunan penelitian beserta pihak sekolah SMP NEGERI 1 Sindangkerta yang telah memberikan izin untuk melakukan penelitian disekolah tersebut. 


\section{REFERENSI}

Adilla, D. N., Zanthy, L. S., \& Yuspriyati, D. N. (2020). Karakteristik Kesalahan Siswa Smp Dalam Menyelesaikan Soal Pada Materi Lingkaran. Teorema: Teori Dan Riset Matematika, 5(1), 35. https://doi.org/10.25157/teorema.v5i1.3220

Hadjar, I. (2014). Perbandingan kemampuan siswa dalam pemecahan masalah segiempat dengan contextual teaching and learning (CTL) dan pembelajaran konvensional di Kelas VII SMPN 7 Palu. AKSIOMA : Jurnal Matematika Dan Pendidikan Matematika, 3(1), 1-9.

Hakim, M. N. (2019). Manajemen Hubungan Masyarakat Dalam Mengembangkan Lembaga Pendidikan (Studi Kasus di SMK Negeri 1 Dlanggu Mojokerto). Nidhomul Haq: Jurnal Manajemen Pendidikan Islam, 4(1), 121-139. https://doi.org/10.31538/ndh.v4i1.245

Hanifah, N. (2019). Pengembangan instrumen penilaian Higher Order Thinking Skill ( HOTS ) di sekolah dasar. Conference Series, 1(1), 1-8. Retrieved from http://ejournal.upi.edu/index.php/crecs/article/view/14286

Magfirah, M., Maidiyah, E., \& Suryawati, S. (2019). Analisis Kesalahan Siswa Dalam Menyelesaikan Soal Cerita Matematika Berdasarkan Prosedur Newman. Lentera Sriwijaya: Jurnal Ilmiah Pendidikan Matematika, 1(2), 1-12. https://doi.org/10.36706/jls.v1i2.9707

Majid, R. A., \& Abadi, A. P. (2019). Pemahaman Konsep Matematis Siswa pada Materi Segitiga dan Segiempat. Prosiding Sesiomadika, 2(1e), 1236-1247.

Muzaky, muhamad farhan. (2017). Muhammad Farhan Muzaky. Analisis Kesalahan Siswa Dalam Menyelesaikan Soal Matematika Pada Materi Segitiga Dan Segiempat, 1(1), 7.

Nurdiana, R., \& Asmah, S. N. (2014). Pengembangan Kemampuan Representasi Matematis untuk Meningkatkan Number Sense Siswa melalui Soal Berbasis Open Ended. 3(3), 738-748.

Purwasih, R. (2015). Peningkatan Kemampuan Pemahaman Matematis Dan Self Confidence Siswa MTs Di Kota Cimahi Melalui Model Pembelajaran Inkuiri Terbimbing. Jurusan Pendidikan Matematika, STKIP Siliwangi Bandung, 9(1), 16-25. Retrieved from http://ejournal.stkipsiliwangi.ac.id/index.php/didaktik/issue/view/18

Shulhani. (2013). Analisis Peranan Guru Dalam Mengembangkan Perilaku Bertanggung Jawab Pada Anak Usia 5-6 Tahun. Jurnal Pendidikan Dan Pembelajaran, 2(12).

Trianto. (2007). Model-model pembelajaran inovatif berorientasi konstruktivistik. Jakarta: prestasi pustaka.

Zakiah, N. E., Fatimah, A. T., \& Sunaryo, Y. (2020). Implementasi Project-Based Learning Untuk Mengeksplorasi Kreativitas Dan Kemampuan Berpikir Kreatif Matematis Mahasiswa. Teorema: Teori Dan Riset Matematika, 5(2), 286. https://doi.org/10.25157/teorema.v5i2.4194

Zulfah, Z. (2017). Analisis Kesalahan Peserta Didik Pada Materi Persamaan Linear Dua Variabel Di Kelas Viii Mts Negeri Sungai Tonang. Jurnal Cendekia: Jurnal Pendidikan Matematika, 1(1), 12 16. 